\title{
The COVID-19 Pandemic Reminds Us of the Importance of Primary Immune Defences
}

\section{Shaw Watanabe*}

Life Science Promoting Association, Japan

*Corresponding Author: Shaw Watanabe, Life Science Promoting Association, Japan.

Starting February $3^{\text {rd }}, 2020$, a coronavirus outbreak among passengers and crew on a cruise ship led to their quarantine in the port of Yokohama, Japan. They stayed nearly 4 weeks on board. By the end of the quarantine period, 712 cases of COVID-19 had been diagnosed among passengers and crew members [1].

As of the 11th of May, 4,118,783 cases have become COVID-19 pneumonia worldwide. There are 282,947 dead and the overall crude mortality rate is $6.9 \%$. Excluding cases with onset on cruise ships, the current number of infected people is 16,6551 and 670 dead (4\%) in Japan, so it can be said that preventive measures have been successful, compared to the global pandemic situation. The Japanese government has begun to implement unprecedented regulations, such as school closures, suspension of meetings and parties, and restrictions on border entries from China and South Korea.

The speed of the epidemic is surprising, but we should keep in mind that infected people had never been exposed, had no immunity, and were therefore naïve to infection [2]. Coronavirus pandemics, such as SARS (Severe Acute Respiratory Syndrome), MERS (Middle East Respiratory Syndrome) and COVID-19, seem to reappear every eight years. Incidentally, the mortality rate of SARS was 10\%. For MERS it was 44\% in Saudi Arabia and 18\% in Korea among confirmed cases.

Such large differences in mortality rates between countries may reflect differences in resistance to infectious diseases, due to eating habits and lifestyle. For COVID-19 the mortality rate per 100,000 population is 2.988 in Italy and 0.616 in Spain, 0.224 in China, 0.146 in Korea, and 0.019 in Japan. It seems that primary immune response (involving inflammatory cytokines, type-1 interferon, and other factors) might play an important role, in addition to the benefits of care in medical facilities.

Many viruses coexist with humans, such as herpes, HPV and hepatitis C. At the time of the first report of COVID-2019, I thought that the virus was attenuated and had already adapted to humans, like herpes, because younger person seems not to develop pneumonia. Now it's better to look for a coexistence with virus than an absolute exclusion from our environment.
Received: March 23, 2020

Published: May 13, 2020

(C) All rights are reserved by Shaw Watanabe.

The coronavirus receptor is an ACE (angiotensin converting enzyme) receptor distributed on cells of the upper respiratory tract. Reducing virus-cell interactions at an early stage might be a way to control the onset of the disease. Viral infectivity depends on interactions between components of the host cell plasma membrane and the virus envelope. Baglivo., et al. [3] found that certain molecules are able to reduce the infectivity of some coronaviruses, possibly by inhibiting viral lipid-dependent attachment to host cells.

Human genomic DNA contains as much as $8 \%$ of so-called endogenous viral elements, which are the signature of a long evolutionary process responsible for RNA-mediated immunity. Noncoding small RNAs (micro RNAs), from such part might block the replication of viral RNA. At this time, miRNAs are considered to be the most important mechanism of post-transcriptional regulation. MicroRNAs are not functioning singly but cooperate with other types of miRNAs to suppress gene expression of mRNAs [4].

Antiviral drugs and vaccine development are urgently needed for COVID-2019, but in the meantime individuals should keep strong immune defenses.

The Chinese Society of Dietician and People's Liberation Army have issued recommendations on optimal energy and protein intakes. Daily meals should include 250 - 400g of cereals (including rice, flour, millet, etc.), and 150 - $200 \mathrm{~g}$ of meat and fish, that contain $30 \mathrm{~g}-40 \mathrm{~g}$ of proteins.

A report by Fei Zhou., et al. [5] describes the clinical course of COVID-19 patients admitted in Wuhan until January 31. Of the 191 cases reported, 137 were discharged and 54 died. Undescribed Deaths without complications might reflect poor immunity due to malnutrition, as suggested by low serum albumin levels and low lymphocyte count. Adequate nutrition should be among priorities for treatment, as there is no remedy yet.

In Hong Kong, corona virus seemed to transfer to dogs. So, it would become a Zoonotic infection Intestinal function is important for enhancing immune capacity [4]. We found that brown rice stabilizes the intestinal microbiota, by producing short chain fatty acids that inhibit pathogenic fusobacteria. High butyrate production 
affects various functions beyond the intestine. Brown rice eating habit is the easiest and most economical way to protect ourselves [6].

\section{Bibliography}

1. Kakimoto K., et al. "Initial investigation of transmission of COVID-19 among crew members during quarantine of a cruise ship - Yokohama, Japan, February 2020". Morbidity and Mortality Weekly Report 69.11 (2020): 312-313.

2. Cucinotta D and Vanelli M. "WHO declares COVID-19 a pandemic". Acta BioMedica 91.1 (2020): 157-160.

3. Baglivo M., et al. "Natural small molecules as inhibitors of coronavirus lipid-dependent attachment to host cells: a possible strategy for reducing SARS-COV-2 infectivity?" Acta BioMedica 91.1 (2020): 161-164.

4. Watanabe S. "MicroRNA opens up a new world for nutrition research”. Acta Scientific Nutritional Health 4.1 (2019): 38-39.

5. Zhou F., et al. "Clinical course and risk factors for mortality of adult inpatients with COVID-19 in Wuhan, China: a retrospective cohort study". The Lancet 395.10229 (2020): 1054-1062.

6. Watanabe S., et al. "What should we eat for healthy longevity? Necessity of tailor-made nutrition". Acta Scientific Nutritional Health 4.3 (2020): 1-5.

\section{Assets from publication with us}

- Prompt Acknowledgement after receiving the article

- Thorough Double blinded peer review

- Rapid Publication

- Issue of Publication Certificate

- High visibility of your Published work

Website: https://www.actascientific.com/

Submit Article: https://www.actascientific.com/submission.php Email us: editor@actascientific.com

Contact us: +91 9182824667 